San Jose State University

SJSU ScholarWorks

Mineta Transportation Institute Publications

$6-2021$

\title{
Do Multi-Use-Path Accessibility and the Clustering Effect Play a Role in Residents' Choice of Walking and Cycling?
}

Chih-Hao Wang

California State University, Fresno

$\mathrm{Na}$ Chen

University of Cincinnati

Follow this and additional works at: https://scholarworks.sjsu.edu/mti_publications

Part of the Transportation Commons, and the Urban Studies and Planning Commons

\section{Recommended Citation}

Chih-Hao Wang and Na Chen. "Do Multi-Use-Path Accessibility and the Clustering Effect Play a Role in Residents' Choice of Walking and Cycling?" Mineta Transportation Institute Publications (2021).

https://doi.org/10.31979/mti.2021.2011

This Report is brought to you for free and open access by SJSU ScholarWorks. It has been accepted for inclusion in Mineta Transportation Institute Publications by an authorized administrator of SJSU ScholarWorks. For more information, please contact scholarworks@sjsu.edu. 


\section{SJSU San OSE STRA}

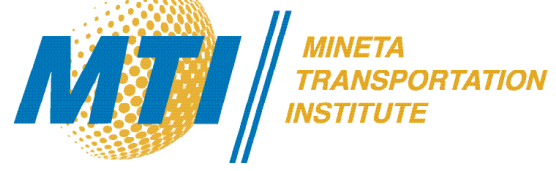

Do Multi-Use Path Accessibility and the Clustering Effect Play a Role in Residents' Choice of Walking and Cycling?

Dr. Chih-Hao Wang

Dr. $\mathrm{Na}$ Chen

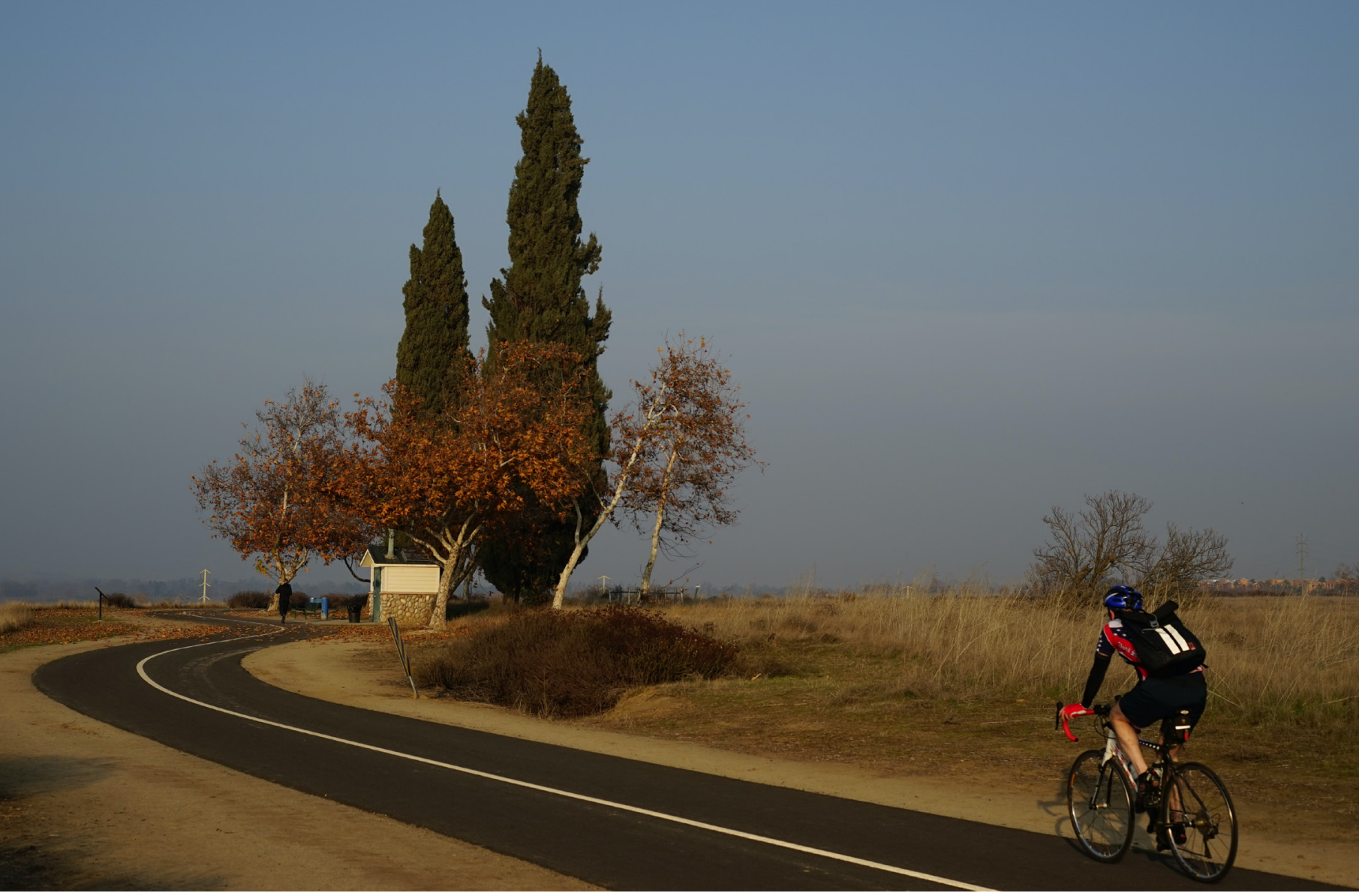




\section{MINETA TRANSPORTATION INSTITUTE}

Founded in 1991, the Mineta Transportation Institute (MTI), an organized research and training unit in partnership with the Lucas College and Graduate School of Business at San José State University (SJSU), increases mobility for all by improving the safety, efficiency, accessibility, and convenience of our nation's transportation system. Through research, education, workforce development, and technology transfer, we help create a connected world. MTI leads the Mineta Consortium for Transportation Mobility (MCTM) funded by the U.S. Department of Transportation and the California State University Transportation Consortium (CSUTC) funded by the State of California through Senate Bill I. MTI focuses on three primary responsibilities:

\section{Research}

MTI conducts multi-disciplinary research focused on surface transportation that contributes to effective decision making. Research areas include:active transportation; planning and policy; security and counterterrorism; sustainable transportation and land use; transit and passenger rail; transportation engineering; transportation finance; transportation technology; and workforce and labor. MTI research publications undergo expert peer review to ensure the quality of the research.

\section{Education and Workforce Development}

To ensure the efficient movement of people and products, we must prepare a new cohort of transportation professionals who are ready to lead a more diverse, inclusive, and equitable transportation industry. To help achieve this, MTI sponsors a suite of workforce development and education opportunities. The Institute supports educational programs offered by the Lucas Graduate School of Business: a Master of Science in Transportation Management, plus graduate certificates that include High-Speed and Intercity Rail Management and Transportation Security Management. These flexible programs offer live online classes so that working transportation professionals can pursue an advanced degree regardless of their location.

\section{Information and Technology Transfer}

MTI utilizes a diverse array of dissemination methods and media to ensure research results reach those responsible for managing change. These methods include publication, seminars, workshops, websites, social media, webinars, and other technology transfer mechanisms. Additionally, MTI promotes the availability of completed research to professional organizations and works to integrate the research findings into the graduate education program. MTI's extensive collection of transportation-related publications is integrated into San José State University's world-class Martin Luther King, Jr. Library.

\section{Disclaimer}

The contents of this report reflect the views of the authors, who are responsible for the facts and accuracy of the information presented herein. This document is disseminated in the interest of information exchange. MTl's research is funded, partially or entirely, by grants from the U.S. Department of Transportation, the U.S. Department of Homeland Security, the California Department of Transportation, and the California State University Office of the Chancellor, whom assume no liability for the contents or use thereof. This report does not constitute a standard specification, design standard, or regulation. 


\section{Do Multi-Use Path Accessibility and the Clustering Effect Play a Role in Residents' Choice of Walking and Cycling?}

Dr. Chih-Hao Wang

Dr. $\mathrm{Na}$ Chen

June 2021
A publication of the Mineta Transportation Institute

Created by Congress in 1991

College of Business

San José State University San José, CA 95192-0219 


\section{TECHNICAL REPORT DOCUMENTATION PAGE}

\begin{tabular}{|c|c|c|c|}
\hline $\begin{array}{l}\text { 1. Report No. } \\
21-12\end{array}$ & 2. Government Accession No. & \multicolumn{2}{|c|}{ 3. Recipient's Catalog No. } \\
\hline \multicolumn{2}{|l|}{ 4. Title and Subtitle } & \multicolumn{2}{|l|}{ 5. Report Date } \\
\hline \multirow{2}{*}{\multicolumn{2}{|c|}{$\begin{array}{l}\text { Do Multi-Use-Path Accessibility and Clustering Effect Play a Role in } \\
\text { Residents' Choice of Walking and Cycling? }\end{array}$}} & \multicolumn{2}{|l|}{ June 2021} \\
\hline & & \multicolumn{2}{|c|}{$\begin{array}{l}\text { 6. Performing Organization } \\
\text { Code }\end{array}$} \\
\hline \multicolumn{2}{|l|}{$\begin{array}{l}\text { 7. Authors } \\
\text { Chih-Hao Wang, PhD } \\
\mathrm{Na} \text { Chen, } \mathrm{PhD}\end{array}$} & \multicolumn{2}{|c|}{$\begin{array}{l}\text { 8. Performing Organization } \\
\text { Report } \\
\text { CA-MTI- } 2011\end{array}$} \\
\hline \multirow{2}{*}{\multicolumn{2}{|c|}{$\begin{array}{l}\text { 9. Performing Organization Name and Address } \\
\text { Mineta Transportation Institute } \\
\text { College of Business } \\
\text { San José State University San José, CA 95192-0219 }\end{array}$}} & \multicolumn{2}{|c|}{ 10. Work Unit No. } \\
\hline & & \multicolumn{2}{|c|}{$\begin{array}{l}\text { 11. Contract or Grant No. } \\
\text { ZSB12017-SJAUX }\end{array}$} \\
\hline \multirow{2}{*}{\multicolumn{2}{|c|}{$\begin{array}{l}\text { 12. Sponsoring Agency Name and Address } \\
\text { State of California SB1 2017/2018 } \\
\text { Trustees of the California State University } \\
\text { Sponsored Programs Administration } \\
\text { 401 Golden Shore, } 5^{\text {th }} \\
\text { Long Beach, CA } 90802\end{array}$}} & \multicolumn{2}{|c|}{$\begin{array}{l}\text { 13. Type of Report and Period } \\
\text { Covered } \\
\text { Final Report }\end{array}$} \\
\hline & & \multicolumn{2}{|c|}{ 14. Sponsoring Agency Code } \\
\hline \multicolumn{4}{|l|}{ 15. Supplemental Notes } \\
\hline \multicolumn{4}{|l|}{ 16. Abstract } \\
\hline \multicolumn{4}{|c|}{$\begin{array}{l}\text { The transportation studies literature recognizes the relationship between accessibility and active travel. However, there } \\
\text { is limited research on the specific impact of walking and cycling accessibility to multi-use paths on active travel } \\
\text { behavior. Combined with the culture of automobile dependency in the US, this knowledge gap has been making it } \\
\text { difficult for policy-makers to encourage walking and cycling mode choices, highlighting the need to promote a } \\
\text { walking and cycling culture in cities. In this case, a clustering effect ("you bike, I bike") can be used as leverage to } \\
\text { initiate such a trend. This project contributes to the literature as one of the few published research projects that } \\
\text { considers all typical categories of explanatory variables (individual and household socioeconomics, local built } \\
\text { environment features, and travel and residential choice attitudes) as well as two new variables (accessibility to multi- } \\
\text { use paths calculated by ArcGIS and a clustering effect represented by spatial autocorrelation) at two levels (level 1: } \\
\text { binary choice of cycling/waking; level 2: cycling/walking time if yes at level 1) to better understand active travel } \\
\text { demand. We use data from the } 2012 \text { Utah Travel Survey. At the first level, we use a spatial probit model to identify } \\
\text { whether and why Salt Lake City residents walked or cycled. The second level is the development of a spatial } \\
\text { autoregressive model for walkers and cyclists to examine what factors affect their travel time when using walking or } \\
\text { cycling modes. The results from both levels, obtained while controlling for individual, attitudinal, and built- } \\
\text { environment variables, show that accessibility to multi-use paths and a clustering effect (spatial autocorrelation) } \\
\text { influence active travel behavior in different ways. Specifically, a cyclist is likely to cycle more when seeing more cyclists } \\
\text { around. These findings provide analytical evidence to decision-makers for efficiently evaluating and deciding between } \\
\text { plans and policies to enhance active transportation based on the two modeling approaches to assessing travel behavior } \\
\text { described above. }\end{array}$} \\
\hline 17. Key Words & \multicolumn{3}{|l|}{ 18. Distribution Statement } \\
\hline $\begin{array}{l}\text { Accessibility, Clustering effect, } \\
\text { Walking, Cycling, Spatial statistics }\end{array}$ & \multicolumn{3}{|c|}{$\begin{array}{l}\text { No restrictions. This document is available to the public through The } \\
\text { National Technical Information Service, Springfield, VA } 22161 .\end{array}$} \\
\hline $\begin{array}{l}\text { 19. Security Classif. (of this report) } \\
\text { Unclassified }\end{array}$ & $\begin{array}{l}\text { 20. Security Classif. (of this page) } \\
\text { Unclassified }\end{array}$ & $\begin{array}{l}\text { 21. No. of Pages } \\
25\end{array}$ & 22. Price \\
\hline
\end{tabular}

Form DOT F 1700.7 (8-72) 
Copyright (C) 2021

\section{by Mineta Transportation Institute}

All rights reserved.

DOI: 10.31979/mti.2021.2011

Mineta Transportation Institute

College of Business

San José State University

San José, CA 95192-0219

Tel: (408) 924-7560

Fax: (408) 924-7565

Email: mineta-institute@sjsu.edu

transweb.sjsu.edu/research/2011 


\section{ACKNOWLEDGMENTS}

This research was supported by the 2020 research grant awarded by the Fresno State Transportation Institute (FSTI) at California State University, Fresno through the California State University Transportation Consortium.

The authors thank Editing Press for editorial services, as well as MTI staff. 


\section{COnTENTS}

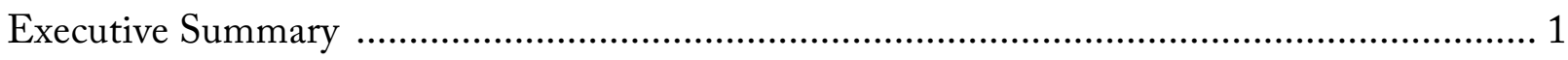

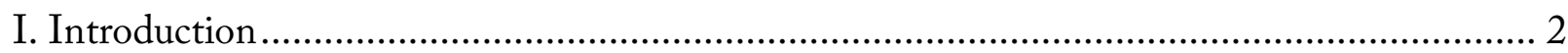

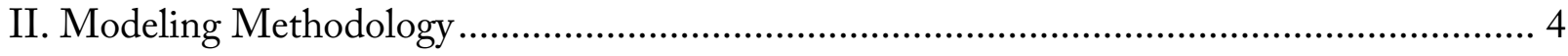

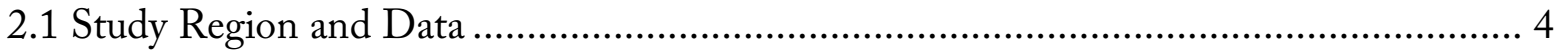

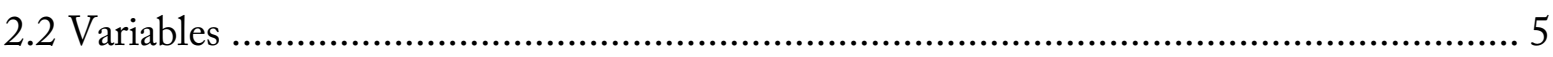

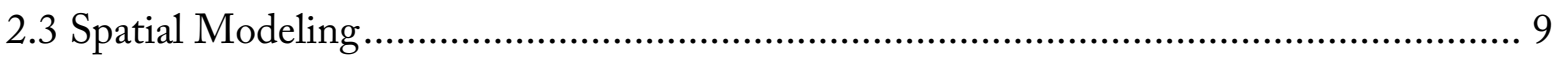

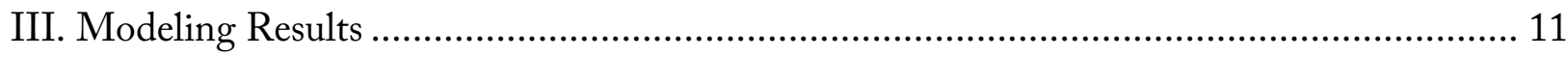

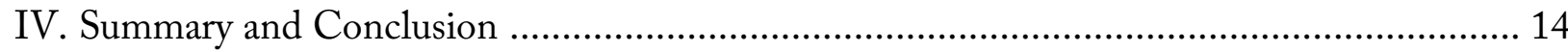

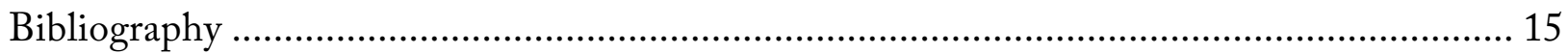

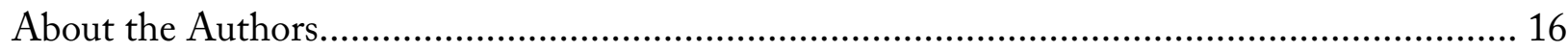




\section{LIST OF FIGURES}

Figure 1. Study Region: Salt Lake City (Wasatch Front), Utah............................................. 4

Figure 2. Distribution of Total Walking and Biking Time .................................................. 6

Figure 3. Distribution of Land Use Entropy ................................................................. 7

Figure 4. Distribution of Weight Accessibility ................................................................. 8 


\section{LIST OF TABLES}

Table 1. Descriptive Statistics of Key Variables......................................................... 5

Table 2. Binary Spatial Probit Modeling Results .......................................................... 12

Table 3. Spatial Autoregressive (SAR) Modeling Results ............................................... 13 


\section{Executive Summary}

The main purpose of this research is to reveal (1) what factors affect people's choice of walking or cycling, and (2) what factors encourage walkers and cyclists do so more frequently. We focus on the effects of accessibility to multi-use paths and the clustering effect.

Accessibility to multi-use paths (MUPs) by walking or cycling is calculated for Salt Lake City, Utah; the accessibility measure indicates the total length of multi-use paths (walkway and bikeway) a resident could reach from the household location within a 15 -min walking distance or a 20-min cycling distance based on the average travel time from the 2012 Utah Travel Survey. We estimate two spatial models at two levels to understand the impact of MUP accessibility and the clustering effect (spatial autocorrelation) on people's active travel behavior. First, a spatial probit model is estimated to identify whether and why people walk or cycle. Second, a spatial autoregressive model is estimated to examine what factors would encourage walkers or cyclists to spend more time walking and cycling.

Our main methodological contribution is the consideration of all typical categories of explanatory variables (individual and household socioeconomics, local built-environment features, and travel and residential choice attitudes) as well as two new variables (MUP accessibility and the clustering effect) which have often been neglected in past travel behavior studies. Interestingly, the modeling results reveal that a resident who bikes more likely lives with their neighbors who do not do so. Further, residents who have been cycling or walking are likely to do so more when they see others doing so. Moreover, MUP accessibility by walking or cycling only has an influence on those who have been walking or cycling. In other words, residents would not necessarily cycle or walk just because they live in a neighborhood with good accessibility to multi-use paths, implying that it is necessary to combine other non-physical measures for the promotion of active transportation. These results suggest that decisionmakers should design and implement active transportation policies and plans differently for the doers (walkers and cyclists) and non-doers. 


\section{Introduction}

In the context of transportation, the general concept of accessibility has been commonly and consistently understood as the ability to obtain resources or participate in activities (urban opportunities, in this research) using one or multiple transportation modes under certain constraints (Cascetta, Cartenì, \& Montanino, 2016). Among the four typical measures for accessibility (infrastructure-based, location-based, person-based, and utility-based), the cumulative-opportunity approach has been widely adopted in accessibility studies for its advantages in easy operationalization, interpretation, and communication (Geurs \& Van Wee, 2004). This approach counts the total number of urban opportunities available within a spatial scale determined by a specific travel time threshold. Our research focuses on accessibility to multi-use paths (MUPs) based on the need to understand the linkage between active transportation and physical activities for promoting transportation sustainability and public health.

This study operationalizes and analyzes accessibility to MUPs for Fresno, CA, motivated by the gap in accessibility to MUP among certain social groups, such as teenagers. Following the need to reduce this gap, from the supply perspective, Wang and Chen (2020) developed a multi-objective optimization modeling framework to find an optimal allocation of green transportation investments to minimize the difference in accessibility to multi-use paths, which was calculated in Chen and Wang (2020) between economically better-off and worse-off communities in Fresno, CA, while maximizing the total MUP accessibility across the city. However, one might argue that these allocations should also account for users' perception of these active transportation infrastructures and their travel habits, which explains the background of this study from the user side. Distinct from most past studies which focus only on the relationships between the usage of multi-use paths (e.g., walkway and bikeway facilities) as well as the built environment features and socioeconomics, this study is one of the limited studies to look at the association between accessibility to active transportation networks and the usage of related infrastructure.

In addition to the impact of accessibility to MUPs, this study also focuses on investigating the clustering effect, referred as spatial autocorrelation (SA), which is often defined as the effect whereby someone's behavior might be affected by their neighbors' choices. The analysis of the clustering effect could help decision-makers identify whether they could promote active travel using this effect as a means of fashioning a culture (when SA is positive) of walking or cycling (Wang, Akar, \& Guldmann, 2015). It is also possible to have negative SA, which implies that residents and their neighbors might make very different travel mode choices due to other reasons such as using gyms for exercise instead of multi-use paths (Chen, Lindsey, \& Wang, 2019).

Using the calculated accessibility to MUP by walking and cycling for Salt Lake City in Utah, using the approach in Chen and Wang (2020), this research explores the impact of accessibility to MUP and clustering effects (spatial autocorrelation) on people's walking and cycling behavior at two levels. First, a spatial probit model is estimated to investigate whether and why people walk or cycle. Second, a spatial autoregressive model is estimated to examine what factors would encourage existing walkers and/or cyclists to do so more (in terms of travel time). The consideration of typical 
explanatory variables (e.g., socioeconomics, the built environment, and attitudes) together with our two focal factors (MUP accessibility and spatial autocorrelation) in both models/levels is very rare in the literature. The main purpose of this research is to determine whether those who do not walk or cycle at all refrain because of the lack of accessibility to multi-use paths or because of their negative travel attitudes toward walking or cycling; for those people who already walk or cycle, the aim is to determine whether MUP accessibility increases their travel time spent walking or cycling. The findings will help decision-makers better understand whether relevant strategies and policies should focus on physical (e.g., accessibility to MUP) or non-physical components (e.g., culture shift, attitudes towards walking and cycling), whether these strategies and plan should be designed separately for different groups, and whether the clustering effect could be used as leverage to encourage existing walkers and cyclists to maintain or increase their habit of active travel. 


\section{Modeling Methodology}

\subsection{Study Region and Data}

The analytical framework elaborated above is applied to data from the Salt Lake metropolitan region in Utah, which is the largest urbanized region and the fastest-growing in this state. Figure 1 depicts the study region along with the population density in 2012 as our main dataset for modeling is the 2012 Utah Travel Survey. This survey collected 2,825 valid individual responses for respondents' one-day travel activities and travel attitudes. Based on this survey, other GIS data were assembled to calculate the built-environment variables (e.g., land use entropy, accessibility to MUP) from the County Auditor, OpenStreetMap (OSM), and the US Census Bureau.

Figure 1. Study Region: Salt Lake City (Wasatch Front), Utah

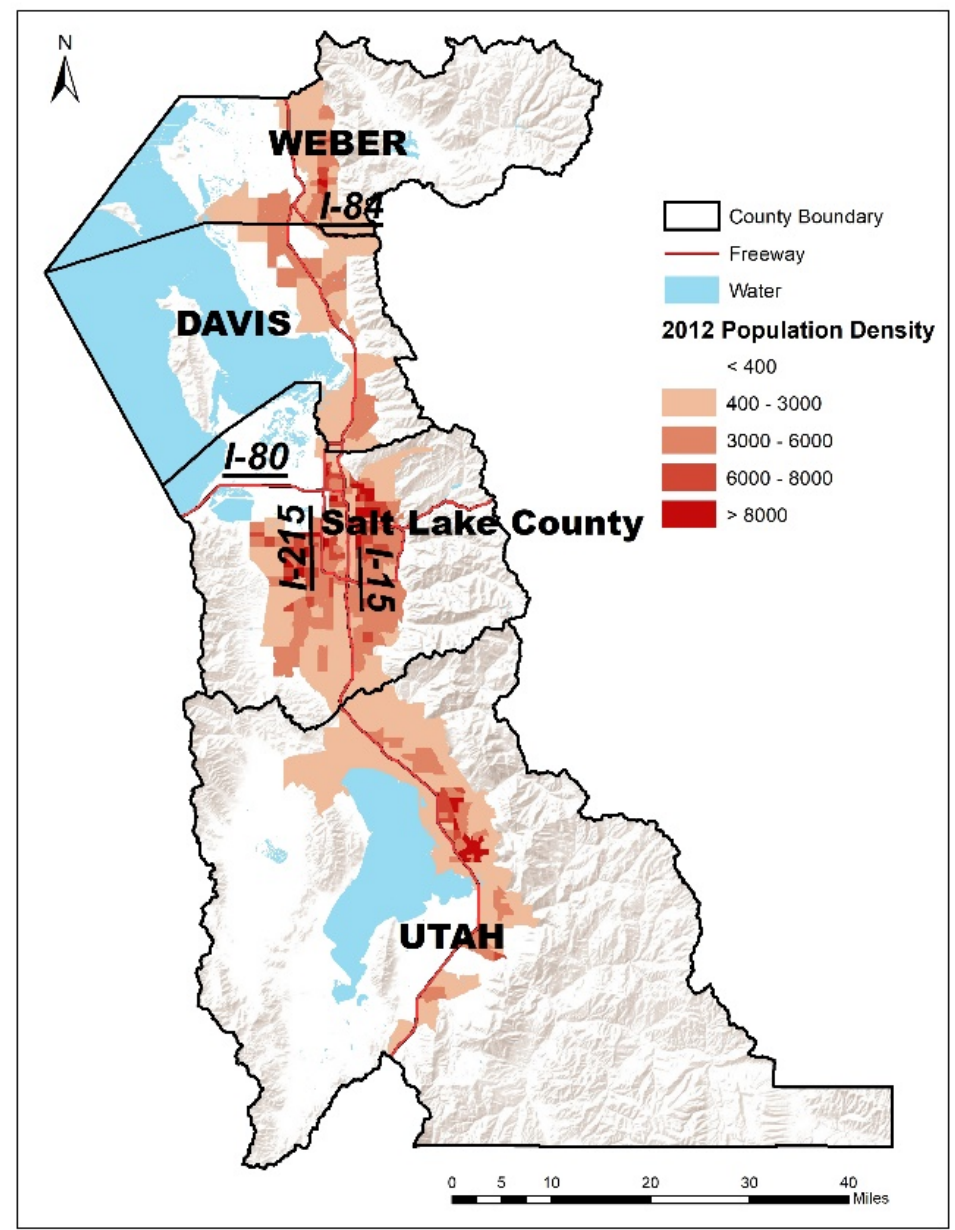




\subsection{Variables}

Table 1 summarizes the key variables used in this study's modeling. Figures 2 and 3 display the spatial distribution of calculated total walking and biking time in minutes as well as land use entropy.

Table 1. Descriptive Statistics of Key Variables

\begin{tabular}{|c|c|c|c|c|}
\hline Name & Description & $\mathbf{N}$ & Mean & S.D. \\
\hline \multicolumn{5}{|c|}{ Trip Variables (individual level) } \\
\hline any_walk_bike & $\begin{array}{l}\text { Dummy variable, } 1=\text { having any walk or bike } \\
\text { trip during the survey day, } 0=\text { no }\end{array}$ & 2,825 & 0.22 & 0.42 \\
\hline walk_bike_time & Total walking and biking time (minutes) & 627 & 8.25 & 26.22 \\
\hline \multicolumn{5}{|c|}{ Socioeconomic Variables (individual and household level) } \\
\hline female & Dummy variable, $1=$ female, $0=$ male & 2,825 & 0.50 & 0.50 \\
\hline age & Age of the person & 2,825 & 30.56 & 20.53 \\
\hline hh_adults & Number of adults in the household & 2,825 & 2.17 & 0.77 \\
\hline employed & Number of workers in the household & 2,825 & 1.39 & 0.77 \\
\hline vehcap & Vehicle ownership per capita & 2,825 & 0.68 & 0.41 \\
\hline num_bikes_adult & Number of bikes for adults in the household & 2,825 & 1.64 & 1.44 \\
\hline sf & $\begin{array}{l}\text { Dummy variable, } 1=\text { if the household lives in a } \\
\text { single-family home, } 0=\text { not }\end{array}$ & 2,825 & 0.75 & 0.43 \\
\hline hispanic & Dummy variable, $1=$ Hispanic, $0=$ otherwise & 2,825 & 0.04 & 0.19 \\
\hline \multicolumn{5}{|c|}{ Built Environment Variables (half-mile buffer around household location) } \\
\hline jobpop & Job-population balance within the buffer & 2,825 & 0.56 & 0.26 \\
\hline entropy & Land use entropy within the buffer & 2,825 & 0.32 & 0.26 \\
\hline pct4way & $\begin{array}{l}\text { Percentage 4-way intersections within the } \\
\text { buffer }\end{array}$ & 2,825 & 21.52 & 15.45 \\
\hline pctemp20mina & $\begin{array}{l}\text { Percentage of regional employment within } 20 \\
\text { minutes by car }\end{array}$ & 2,825 & 27.92 & 17.53 \\
\hline accpath $20 \mathrm{~b}$ & $\begin{array}{l}\text { Accessibility to multi-use path by biking ( } 20 \\
\text { minutes) }\end{array}$ & 2,825 & 128.65 & 122.22 \\
\hline accpath $15 \mathrm{w}$ & $\begin{array}{l}\text { Accessibility to multi-use paths by walking } \\
\text { (15 minutes) }\end{array}$ & 2,825 & 9.75 & 23.56 \\
\hline accpath_wgt & $\begin{array}{l}\text { Weighted accessibility with accpath20b }(1 / 5) \\
\text { and accpath } 15 \mathrm{w}(4 / 5) \text { considering the } \\
\text { proportions of cyclists and walkers in the } \\
\text { survey }\end{array}$ & 2,825 & 33.08 & 33.03 \\
\hline
\end{tabular}


Figure 2. Distribution of Total Walking and Biking Time

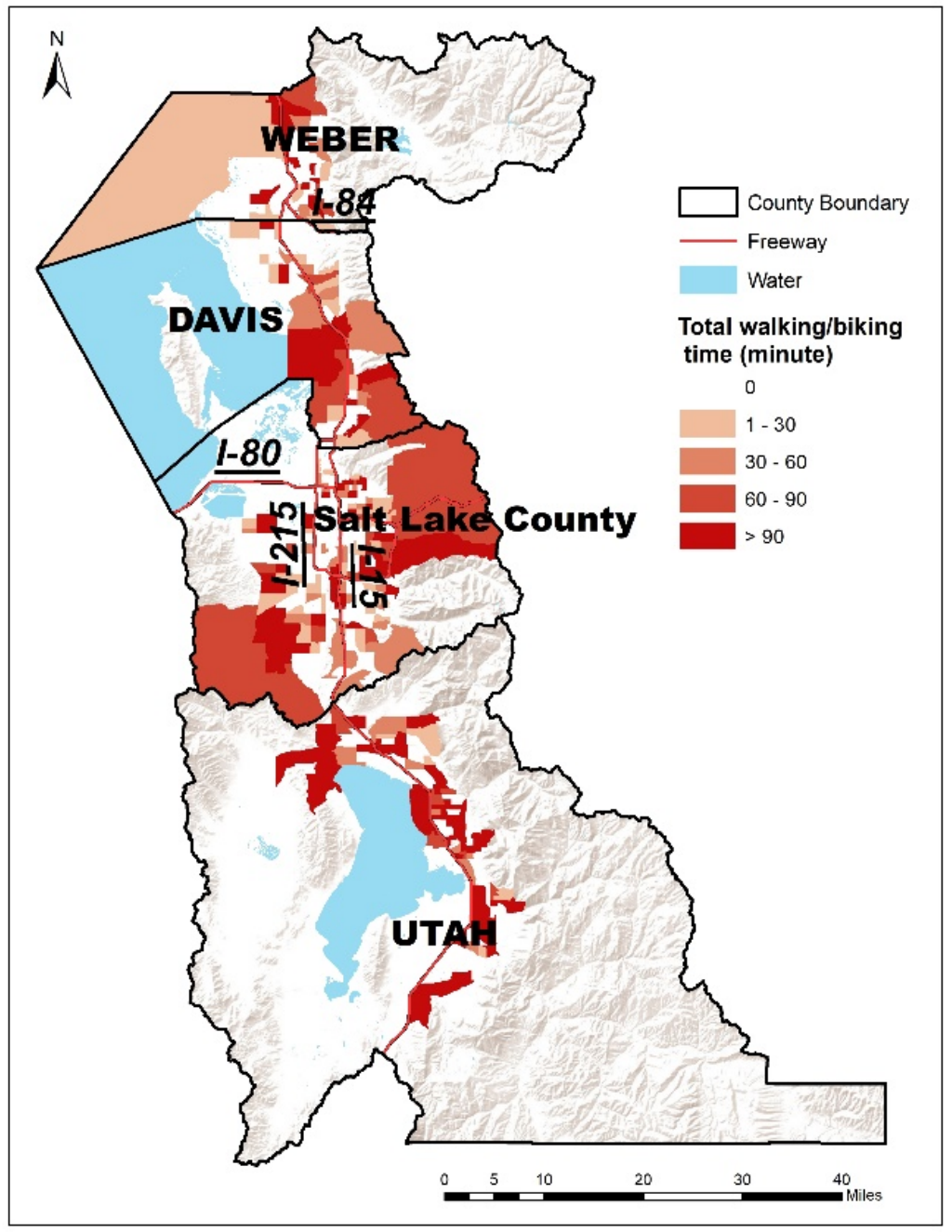


Figure 3. Distribution of Land Use Entropy

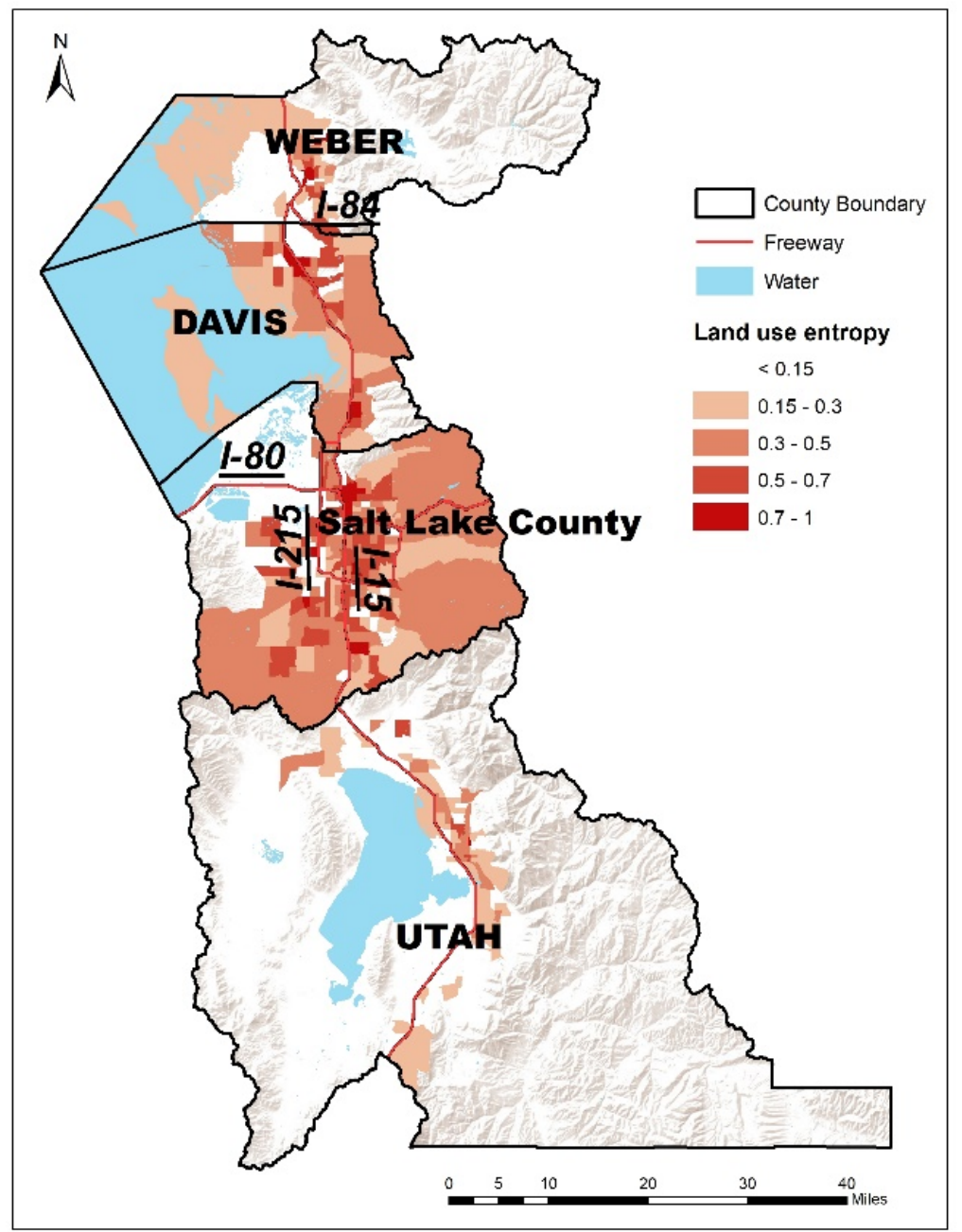

\section{Accessibility to Multi-Use Paths}

We calculate accessibilities to MUP by walking and cycling separately using the cumulativeopportunity approach adopted in a previous paper (Chen \& Wang, 2020), where it is defined as the total length (miles) of multi-use paths within a 15-min walking distance or a 20-min cycling distance based on the average travel time from the survey. The equation is specified as follows:

$A_{i}^{\text {path_m }}=\sum_{j=1}^{J} L_{j} * D_{j}$,

where

- $\quad A_{i}^{\text {path } \_m}:$ a household's (is) accessibility to MUP with mode $m$ (walking and cycling)

- $\quad L_{j}$ : length of path segment $j$

- $D_{j}$ : a dummy variable, which equals 1 if the segment $j$ falls inside the buffer and 0 otherwise.

We then weight the calculated accessibility values using equation (1) into one accessibility value for both modes, considering the distribution of walking and cycling in the survey: 
weighted $A_{i}^{\text {path }}=\left(\frac{1}{5}\right) * A_{i}^{\text {path_biking }}+\left(\frac{4}{5}\right) * A_{i}^{\text {path_walking }}$.

This weighted accessibility result is mapped out in Figure 4.

Figure 4. Distribution of Weighted Accessibility

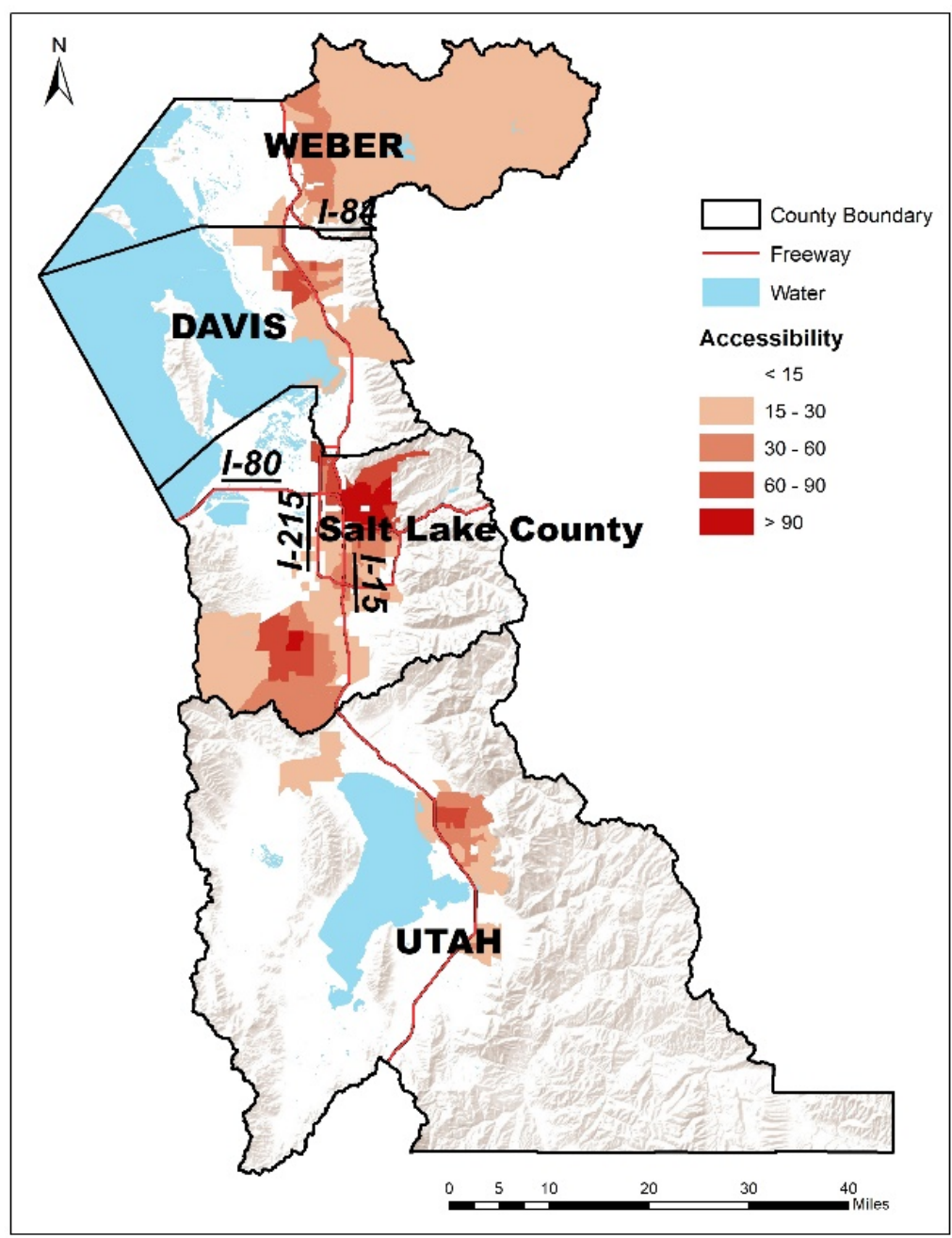

\section{Principal Component Analysis}

The survey results report responses to over 40 attitude statements to collect residents' attitudes on residential location selection and travel behavior. We conduct principal component analysis (PCA) for the two datasets separately based on the two-level modeling approaches: one for all valid respondents in the survey and the other for respondents who reported walking or biking during the survey day. This analysis could reduce the dimensionality of those 40 statements into a smaller number of attitudinal variables, as shown below.

We first categorize all valid respondents in the survey with the 40 attitude statements mentioned above into the following $12 \mathrm{PCA}$ results: 
- PC1: preferring an easy walk to daily living activities

- PC2: preferring to use non-auto transportation modes

- PC3: living in a diverse and inclusive community

- PC4: preferring to live in a mixed-land-use and walkable community with good transit access

- PC5: living in a community far away from transit facilities and commercial areas

- PC6: preferring a more environmentally-friendly and non-sprawling development strategy

- PC7: preferring to live in a community with easy walking access to spiritual and educational places

- PC8: living in a walkable and accessible community

- PC9: preferring sustainable and "smart" urban development

- PC10: negative attitude towards community development

- PC11: preferring to live in a well-maintained community but away from others

- PC12: living in a more suburban community.

Respondents who walked or biked are then assigned into following 11 PCs with the same set of attitude statements:

- PC1: preferring an easy walk to daily living activities

- PC2: preferring a more environmentally-friendly and non-sprawling development strategy

- PC3: living in a mixed-land-use and walkable community with good transit access

- PC4: preferring non-auto transportation modes

- PC5: living in a community far away from transit facilities and commercial areas

- PC6: living in a diverse and inclusive community

- PC7: preferring to live in a community with easy walking access to spiritual and educational places

- PC8: preferring to live in a well-developed and accessible community but away from others

- PC9: negative attitude towards community development

- PC10: preferring to use transit in a well-developed community

- PC11: living in a more suburban community but preferring biking and transit more.

\subsection{Spatial Modeling}

Two spatial models are developed to estimate individual active travel behavior using 2012 travel survey data collected in Salt Lake City, Utah. The first is a spatial probit model designed to investigate the correlates of the binary choice of walking or cycling with 2,850 valid responses from the survey. Based on the random utility theory, the probability function for this model is as follows (LeSage \& Pace, 2009):

$P\left(y=1 \mid x_{p}\right)=P\left(U_{1} \geq U_{0}\right)=P\left(y^{*} \geq 0\right)=F\left([I-\rho W]^{-1} \beta_{p} x_{p}\right)$. 
Here,

- $\quad y$ : chosen alternative, $y=1$ if walking/cycling;

- $y^{*}$ : latent utility, a function of a set of explanatory factors, following a truncated multivariate normal distribution (TMVN);

- $\quad x_{p}$ : a set of explanatory factors;

- $\quad W$ : spatial weight matrix;

- $\beta_{p}$ : parameters;

- $\rho$ : spatial scale.

With this probability function, the formula of the spatial probit model for the choice of walking or cycling is specified as:

$y^{*}=\rho W y^{*}+\beta_{p} x_{p}+\varepsilon$.

The neighbors of a respondent are identified with a set of buffers at $1 / 32,1 / 16$, and 1/8 miles to calculate the spatial weight matrix, $W$. The estimation of spatial scale $\rho$ represents the level of spatial autocorrelation. A positive estimation of spatial scale indicates that people choose to walk or cycle in a similar way as their neighbors as a result of the clustering effect; a negative estimation implies the existence of a competing effect, whereby people behave in a different way from their neighbors.

Moving on to the second level, we estimate a spatial autoregressive (SAR) model to investigate the explanatory factors relevant to total travel time spent walking or cycling using the $22 \%$ of the surveyed respondents $(627$ out of 2,850 ) who walked or cycled at least once during the survey day. The estimation function for this SAR model is:

$g=\gamma W g+\beta_{p} x_{p}+u$

where

- $g$ : logarithm of total walking and cycling time

- $x_{p}$ : a set of explanatory factors

- $W g$ : a spatial lag term

- $\beta_{p}$ : parameters

- $\gamma$ : spatial scale

- $u$ : error term.

The buffers to identify spatial neighbors in the SAR model are created at $1 / 16,1 / 8,1 / 4$, and $1 / 2$ miles. Like $\rho$, the spatial scale $\gamma$ indicates the spatial autocorrelation, which could be either positive or negative. Positive spatial scale $\gamma$ implies that people living a neighborhood with more similar travel or exercise habits would walk or cycle more. Each model has a set of explanatory variables including spatial autocorrelation, accessibility to MUP, other built-environment features, attitudes, and socioeconomic factors. 


\section{Modeling Results}

Each model is run several times with different combinations of explanatory variables. As for the first level, one spatial probit model with the 1/16-mile buffer (with better goodness-of-fit) as well as three regular probit models (non-spatial probit) are presented in Table 2. Probit 1, which accounts for socioeconomics and attitudes, shows that respondents who are female, young, unemployed, and non-Hispanic are more willing to walk or bike. The attitudes categorized through PCA suggest that respondents living in a suburban neighborhood but who reported a preference for easy walking for daily needs during the survey time period are less willing to walk or cycle. Probit 2 and 3 indicate that MUP accessibility is not a significant determinant of active mode choice while controlling for socioeconomic status, attitudes, and some other built environmental features, implying a negligible role of access to active transportation infrastructure in influencing respondents' choice of non-motorized modes. The spatial probit modeling results yield negative spatial autocorrelation, suggesting that respondents who walk or cycle to participate in activities or obtain resources tend to live in a community with people who are less likely to choose these modes.

For the modeling at the second level, those respondents who walked or cycled during the survey period were selected. Three OLS models and one SAR model with the 1/4-mile buffer were estimated, with results presented in Table 3. Those respondents who are older, own more bikes, and live in non-single-family housing walk or cycle for a greater number of minutes. The attitudinal factors explain that respondents who favor mixed-use, walkable, and accessible community infrastructure but live away from others tend to walk or cycle more. Regarding the impact of accessibility to MUP, the results here are different from the probit results, with significant and positive results in this second group of models, indicating that these active transportation facilities play an encouraging role in promoting active travel for those people who reported walking or cycling. The significant but negative effects of employment accessibility and land-use diversity on active travel time seem abnormal and interesting. They could be explained by pointing out that most of those survey respondents who reported walking or cycling for recreational purposes live in affluent communities away from the urban center. The SAR model reports positive and significant spatial autocorrelation, as expected. This finding of a clustering effect provides evidence for the utility of initiating/promoting a culture of walking and cycling. 
Table 2. Binary Spatial Probit Modeling Results

\begin{tabular}{|c|c|c|c|c|c|c|c|c|}
\hline & \multicolumn{2}{|c|}{ Probit 1} & \multicolumn{2}{|c|}{ Probit 2} & \multicolumn{2}{|c|}{ Probit 3} & \multicolumn{2}{|c|}{ Spatial Probit } \\
\hline & Coeff. & $\mathrm{z}$-value & Coeff. & $z$-value & Coeff. & $z$-value & Coeff. & $\mathrm{t}$-value \\
\hline Constant & 0.507 & 4.640 & 0.648 & 4.530 & -0.743 & -4.800 & -1.492 & -8.037 \\
\hline \multicolumn{9}{|c|}{ Socioeconomic Variables (individual and household level) } \\
\hline female & $\begin{array}{r}0.108 \\
-\end{array}$ & $\begin{array}{r}1.960 \\
-\end{array}$ & $\begin{array}{r}0.108 \\
-\end{array}$ & $\begin{array}{r}1.950 \\
-\end{array}$ & 0.125 & 2.220 & 0.125 & 2.217 \\
\hline age & $\begin{array}{r}0.004 \\
-\end{array}$ & $\begin{array}{r}2.440 \\
-\end{array}$ & $\begin{array}{r}0.004 \\
-\end{array}$ & 2.510 & -0.004 & -2.350 & -0.004 & -2.435 \\
\hline employed & $\begin{array}{r}0.230 \\
-\end{array}$ & $\begin{array}{r}5.350 \\
-\end{array}$ & $\begin{array}{r}0.232 \\
-\end{array}$ & $\begin{array}{r}5.390 \\
-\end{array}$ & -0.252 & -5.750 & -0.258 & -5.929 \\
\hline vehcap & 0.429 & 4.710 & 0.436 & 4.780 & -0.414 & -4.480 & -0.418 & -4.624 \\
\hline num_bikes_adult & 0.082 & 4.190 & 0.084 & 4.290 & 0.092 & 4.580 & 0.090 & 4.597 \\
\hline hh_adults & 0.106 & 2.680 & 0.110 & 2.770 & 0.141 & 3.490 & 0.143 & 3.499 \\
\hline hispanic & 0.365 & 2.300 & 0.358 & 2.260 & -0.313 & -1.930 & -0.359 & -2.172 \\
\hline \multicolumn{9}{|c|}{ Attitude Variables (PCA) } \\
\hline PC1 & 0.071 & 4.210 & 0.071 & 4.230 & -0.081 & -4.710 & -0.085 & -4.820 \\
\hline PC & 0.119 & 6.040 & 0.116 & 5.910 & 0.125 & 6.210 & 0.125 & 6.016 \\
\hline PC8 & 0.094 & 4.200 & 0.087 & 3.810 & 0.090 & 3.820 & 0.097 & 4.011 \\
\hline PC12 & 0.056 & 1.990 & -0.055 & -1.940 & -0.040 & -1.390 & -0.040 & -1.369 \\
\hline \multicolumn{9}{|c|}{ Built-Environment Variables } \\
\hline $\begin{array}{l}\ln (\text { accpath_wgt }) \\
\text { jobpop }\end{array}$ & & & 0.045 & 1.530 & $\begin{array}{r}0.042 \\
-0.176\end{array}$ & $\begin{array}{r}1.360 \\
-1.590\end{array}$ & $\begin{array}{r}0.054 \\
-0.184\end{array}$ & $\begin{array}{r}1.504 \\
-1.598\end{array}$ \\
\hline pct4way & & & & & 0.005 & 2.930 & 0.006 & 3.010 \\
\hline Spatial & & & & & & & -0.865 & -6.589 \\
\hline & & & & & & & 2664.8 & \\
\hline AIC & & & & & & & 7 & \\
\hline Pseudo R ${ }^{2}$ & 0.073 & & 0.074 & & 0.083 & & & \\
\hline No. of observations & 2775 & & 2773 & & 2706 & & 2706 & \\
\hline
\end{tabular}

Bold: significance at the 0.05 level. 
Table 3. Spatial Autoregressive (SAR) Modeling Results

\begin{tabular}{|c|c|c|c|c|c|c|c|c|}
\hline & \multicolumn{2}{|c|}{ OLS 1} & \multicolumn{2}{|c|}{ OLS 2} & \multicolumn{2}{|c|}{ OLS 3} & \multicolumn{2}{|c|}{ SAR } \\
\hline & Coeff. & $\mathrm{t}$-value & Coeff. & $t$-value & Coeff. & $\mathrm{t}$-value & Coeff. & $\mathrm{z}$-value \\
\hline & & 36.46 & & 19.80 & & 17.99 & & \\
\hline Constant & 3.420 & 0 & 3.145 & 0 & 3.198 & 0 & 1.314 & 2.715 \\
\hline \multicolumn{9}{|c|}{ Socioeconomic Variables (individual and household level) } \\
\hline age & 0.007 & 3.930 & 0.006 & 3.570 & 0.008 & 4.700 & 0.008 & 4.708 \\
\hline \multirow[t]{2}{*}{ num_bikes_adult } & 0.125 & 5.270 & 0.127 & 5.370 & 0.128 & 5.410 & 0.137 & 5.957 \\
\hline & - & - & - & - & - & - & & - \\
\hline sf & 0.440 & 4.890 & 0.417 & 4.630 & 0.353 & 3.720 & -0.296 & 3.191 \\
\hline \multicolumn{9}{|c|}{ Attitude Variables (PCA) } \\
\hline $\mathrm{PC} 3$ & 0.149 & 6.490 & 0.145 & 6.330 & 0.148 & 6.360 & 0.132 & 5.764 \\
\hline PC5 & 0.153 & 6.350 & 0.173 & 6.710 & 0.142 & 5.150 & 0.141 & 5.265 \\
\hline PC 8 & 0.063 & 2.210 & 0.066 & 2.310 & 0.051 & 1.780 & 0.059 & 2.146 \\
\hline PC9 & 0.101 & 3.500 & 0.104 & 3.600 & 0.098 & 3.370 & 0.091 & 3.202 \\
\hline \multicolumn{9}{|c|}{ Built-Environment Variables } \\
\hline $\ln$ (accpath_wgt) & & & 0.086 & 2.150 & 0.093 & 2.290 & 0.085 & 2.154 \\
\hline \multirow{2}{*}{ pct4way } & & & & & 0.005 & 2.090 & 0.003 & 1.282 \\
\hline & & & & & - & - & & - \\
\hline pctemp20mina & & & & & 0.008 & 3.310 & -0.006 & 2.328 \\
\hline \multirow[t]{3}{*}{ entropy } & & & & & -0.281 & -1.860 & -0.074 & -0.493 \\
\hline & & & & & & & \multirow{2}{*}{\multicolumn{2}{|c|}{$\begin{array}{r}\text { LR test value } \\
18.46\end{array}$}} \\
\hline & & & & & & & & \\
\hline Spatial Scale $(\gamma)$ & & & & & & & 0.508 & \\
\hline AIC & & & & & & & 1442.8 & \\
\hline Adjusted $\mathrm{R}^{2}$ & 0.175 & & 0.180 & & 0.213 & & 0.246 & \\
\hline No. of observations & 613 & & 613 & & 594 & & 594 & \\
\hline
\end{tabular}

Bold: significance at the 0.05 level 


\section{Summary and Conclusion}

The decision to invest in active transportation infrastructure to promote active travel behavior involves a complicated process requiring consideration of many different factors, including an understanding of the public demand for active travel facilities. It is therefore necessary to investigate this demand by accounting for all possible correlates of active mode share, particularly the provision of active transportation facilities in terms of accessibility to MUP and the presence or absence of a walking and cycling culture, both of which formed our focus in this research. As one of the rare studies to include five categories of explanatory variables (individual socioeconomics, attitudes, accessibility to multi-use paths, built-environment features, and clustering effect) in travel behavior research, we develop two spatial models (spatial probit and SAR) at two levels to explain what makes people walk/bike or refrain from using those modes, whether active transportation facilities play a role in walking and cycling, and whether neighbors' choices affect walking and cycling behavior. The models were run on data from the 2012 Utah Travel Survey for Salt Lake City. The key findings from the models are summarized as follows.

- Most typical socioeconomic characteristics (e.g., gender, age, employment, race, bike and vehicle ownership, and number of adults in the household), attitudes towards walking and cycling, and some built-environment features, such as street intersection and land-use diversity, do affect people's decisions about walking and cycling to some extent.

- The current distribution of active transportation investments in terms of accessibility to multiuse paths only plays a role for walkers and cyclists. In other words, providing better MUP accessibility will not necessarily encourage people to start walking and cycling.

- Respondents' active travel behavior is affected by their neighbors in two opposite ways. A clustering effect exists among doers (walkers and cyclists), meaning that walkers/cyclists increase their use of active modes when seeing more doers around in the community.

- Between doers and non-doers, there are competing effects, meaning that a resident who walks or cycles is more likely to live with neighbors who do not do so, possibly due to the lack of trail-activity culture, the preference for using other means for exercise, trail congestion, or different lifestyles. Specifically, a culture of cycling and/or walking does not exist among all residents, indicating the importance of promoting such culture for sustainable transportation.

This study suggests that decision-makers need to design different active transportation strategies to promote active travel for the two different group: doers (walkers and cyclists) and non-doers (non-walkers and non-cyclists). Specifically, for doers, it is important to improve the existing multi-use paths by increasing the amount of MUPs available and facilitating better connectivity as well as creating a walking and cycling culture. For non-doers, it would be more efficient to adopt some non-physical strategies, since the supply of physical infrastructure does not play a role in residents' active travel behavior and a walking or cycling culture might not exist yet. 


\section{Bibliography}

Cascetta, E., A. Cartenì, \& M. Montanino. "A Behavioral Model of Accessibility Based on the Number of Available Opportunities." Journal of Transport Geography 51 (2016): 45-58. https://doi.org/10.1016/j.jtrangeo.2015.11.002

Chen, N., G. Lindsey, \& C.-H. Wang. "Patterns and Correlates of Urban Trail Use: Evidence from the Cincinnati Metropolitan Area." Transportation Research Part D: Transport and Environment 67 (2019): 303-315. https://doi.org/10.1016/j.trd.2018.12.007

Chen, N., \& C.-H. Wang. "Does Green Transportation Promote Accessibility for Equity in Medium-Size U.S. Cites?” Transportation Research Part D: Transport and Environment 84 (2020): 102365. https://doi.org/10.1016/j.trd.2020.102365

Geurs, K. T., \& B. Van Wee. "Accessibility Evaluation of Land-Use and Transport Strategies: Review and Research Directions.” Journal of Transport Geography12, no. 2 (2004): 127140.

LeSage, J., \& R. K. Pace. Introduction to Spatial Econometrics. Chapman and Hall/CRC, 2009. Wang, C.-H., G. Akar, \&J.-M. Guldmann. "Do Your Neighbors Affect Your Bicycling Choice? A Spatial Probit Model for Bicycling to The Ohio State University.” Journal of Transport Geography 42 (2015): 122-130.

Wang, C.-H., \& N. Chen. "A Multi-Objective Optimization Approach to Balancing Economic Efficiency and Equity in Accessibility to Multi-Use Paths." Transportation (2020): 1-20. 


\section{About the Authors}

\section{Chih-Hao Wang, $\mathrm{PhD}$}

Chih-Hao Wang is an associate professor of the Department of Geography and City \& Regional Planning at California State University, Fresno, where he has taught since 2014. He received his $\mathrm{PhD}$ (2013) and Master's (2010) degrees in City and Regional Planning from The Ohio State University. Dr. Wang's research focuses on environmental planning from the perspective of natural hazard mitigation. Another of his research interests is the application of spatial statistics to the analysis of spatial or social interactions in the earthquake process, as well as water management, transportation planning, and community development. His research has been published in journals in environmental planning, transportation, and geography.

\section{$\mathrm{Na}$ Chen, $\mathrm{PhD}$}

$\mathrm{Na}$ Chen is an Assistant Professor in the School of Planning at the University of Cincinnati. She received her BA in Public Policy (2008) from Sun Yat-Sen University, Guangzhou, China, her MA in Community Planning and Public Administration (2011) from Auburn University, AL, and her PhD in City and Regional Planning (2016) from The Ohio State University. She then worked as a postdoctoral scholar in the Department of Technology Management at the University of California, Santa Cruz. Her research interests include transportation planning, activity-based travel behavior modeling, accessibility, activity space, transportation equity, land-use modeling, spatial econometrics, and Geographic Information System (GIS) applications for urban planning. Based on her expertise in her areas of interest, Dr. Chen has published many papers in peerreviewed journals and presented at international conferences. 
Founder, Honorable

Norman Mineta*

Secretary (ret.),

US Department of Transportation

\section{Chair,}

Abbas Mohaddes

President \& $\mathrm{COO}$

Econolite Group Inc.

\section{Vice Chair,}

Will Kempton

Retired Transportation Executive

\section{Executive Director,} Karen Philbrick, PhD*

Mineta Transportation Institute

San José State University

\section{Winsome Bowen}

Chief Regional Transportation

Strategy

Facebook

\section{David Castagnetti}

Co-Founder

Mehlman Castagnetti

Rosen \& Thomas

\section{Maria Cino}

Vice President

America \& U.S. Government

Relations Hewlett-Packard Enterprise

\author{
Grace Crunican** \\ Owner \\ Crunican LLC
}

\section{Donna DeMartino}

Managing Director

Los Angeles-San Diego-San Luis

Obispo Rail Corridor Agency

\section{John Flaherty}

Senior Fellow

Silicon Valley American

Leadership Form

\section{William Flynn *}

President \& CEO

Amtrak

\section{Rose Guilbault}

Board Member

Peninsula Corridor

Joint Powers Board

\section{Ian Jefferies*}

President \& CEO

Association of American Railroads

Diane Woodend Jones

Principal \& Chair of Board

Lea + Elliott, Inc.
David S. Kim*

Secretary

California State Transportation

Agency (CALSTA)

Therese McMillan

Executive Director

Metropolitan Transportation

Commission (MTC)

Jeff Morales

Managing Principal

InfraStrategies, LLC

Dan Moshavi, PhD*

Dean, Lucas College and

Graduate School of Business

San José State University

Toks Omishakin*

Director

California Department of

Transportation (Caltrans)

\section{Takayoshi Oshima}

Chairman \& CEO

Allied Telesis, Inc.

Paul Skoutelas*

President \& CEO

American Public Transportation

Association (APTA)
Beverley Swaim-Staley

President

Union Station Redevelopment

Corporation

Jim Tymon*

Executive Director

American Association of

State Highway and Transportation

Officials (AASHTO)

$*$ = Ex-Officio

** $=$ Past Chair, Board of Trustees

\section{Directors}

\section{Karen Philbrick, PhD}

Executive Director

\section{Hilary Nixon, PhD}

Deputy Executive Director

\section{Asha Weinstein Agrawal, PhD}

\section{Education Director}

National Transportation Finance

Center Director

\section{Brian Michael Jenkins}

National Transportation Security

Center Director

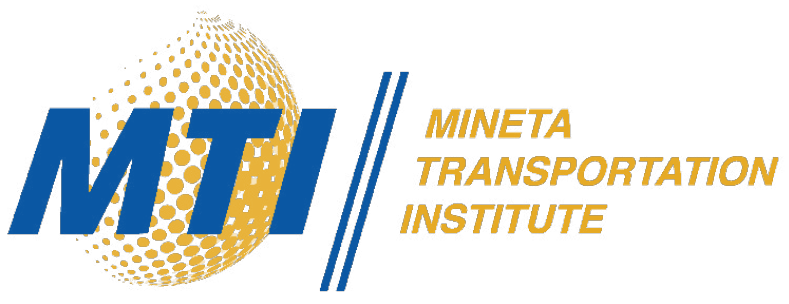

